ORIGINAL

\title{
Swine Carcass Condemnation in Commercial Slaughterhouses
}

\section{Condenaciones de canales porcinas en beneficiaderos}

\author{
Lesley S. Bueno, ${ }^{1}$ M.Sc, Fabiana R. Caldara, ${ }^{1 *}$ Ph.D, Irenilza A. Nääs, ${ }^{1}$ Ph.D, \\ Douglas D. Salgado, ${ }^{2}$ Ph.D, Rodrigo G. García, ${ }^{1}$ Ph.D, Ibiara C.L. Almeida Paz, ${ }^{1}$ Ph.D.
}

\begin{abstract}
${ }^{1}$ Federal University of Grande Dourados- UFGD, College of Agricultural Sciences - FCA, Highway Dourados-Ithaum km 12, Zip Code:79804-970, Dourados, MS, Brazil. 2Pontifical Catholic University of Campinas - PUC - Campinas, Mathematics department, Highway D. Pedro I, km 136, Park of Universities, Zip Code: 13086-900, Campinas, SP, Brazil. *Correspondence: fabianacaldara@ufgd. edu.br
\end{abstract}

Recibido: Noviembre de 2012; Aceptado: Marzo de 2013.

\begin{abstract}
Objective. The research was conducted to evaluate the main causes of carcass condemnation, as well as the financial loss caused by it, at a commercial slaughterhouse located in Dourados, MS, Brazil. Materials and methods. The data related to carcass condemnation, for the years 2007 to 2009 was obtained from a commercial slaughterhouse, located in the city of Dourados, MS, Brazil, and turned into a percentage of the total number of animals slaughtered during that period. The most frequent causes of carcass condemnation (total or partial) were grouped into classes (pleurisy + pneumonia; enteritis; arthritis; abscesses; fractures/hematomas + contusions + death). The financial loss by the slaughterhouse was estimated using the condemnation data. Results. The total rate of carcass condemnation was low and tended to stability $(<0.45 \%)$. The most prevalent causes of condemnation during the study period were abscesses and death in the transport, which together accounted for approximately $40 \%$ of all condemnation. The condemnation due to health problems tended to decrease or to be stable over the years. However, the condemnations caused by management problems (abscesses, fractures, contusions and death) showed a significant increase. The average loss to the integrative company according to the carcasses condemnation was exceeding $U \$ 1,600,000.00$ in the years studied. Conclusions. The main causes of carcass condemnation come from management failure. The annual loss by the company can be invested in the training of manpower in order to reduce the rates of carcass condemnation.
\end{abstract}

Key words: Abattoirs, arthritis, bone fractures, enteritis, respiratory tract diseases (Source: CAB). 


\section{RESUMEN}

Objetivo. La investigación se llevó a cabo para evaluar las principales razones de la condena de canales de cerdo, así como las pérdidas financieras causadas por estas en un beneficiadero comercial ubicado en Dourados, MS, Brazil. Materiales y métodos. Los datos relacionados con la condena de canales, para los años 2007 a 2009, se obtuvieron en un matadero comercial, situado en Dourados, MS, Brazil y fueron convertidos en porcentaje del número total de animales sacrificados durante el período. Se consideraron todas las causas de condena de canales observadas, total y parcial, y las principales (más frecuentes), fueron agrupadas por tipo (pleuresía + neumonía, enteritis, artritis, abscesos, fracturas / hematomas + contusiones + muerte). La pérdida financiera por parte del matadero se estimó utilizando los datos de condena. Resultados. El índice total de condena de canales fue bajo y se mantuvo estable a lo largo de los años $(<0.45 \%)$. Las causas más frecuentes de condena durante el período de estudio fueron los abscesos y las muertes en el transporte, que en conjunto representaron el $40 \%$ de todas las condenas. Los problemas de salud relacionados con la condena tendieron a reducir o estabilizarse a lo largo de los años. Sin embargo, las condenas por problemas de manejo (abscesos, fracturas, contusiones y muertes) presentaron un aumento significativo. La pérdida promedio de la empresa, de acuerdo con la condena de canales fue superior a U\$1.600.000 durante los años estudiados. Conclusiones. Los principales motivos de condena de canales provienen de fallas en la gestión. La suma anualmente de perdidas de la empresa podría invertirse en la capacitación de mano de obra para reducir los índices de condena de canales.

Palabras clave: Artritis, enfermedades de las vías respiratórias, enteritis, fracturas óseas, matadero (Fuente: $C A B$ ).

\section{INTRODUCTION}

Brazilian agribusiness represents $33 \%$ of the country's Gross National Product (GNP); 42\% of the total export and $37 \%$ of the source of employment. Brazil is currently the 4th largest pork producer and exporter in the world, with exports of nearly 520.000 tons during 2011 and income of $\mathrm{U} \$ 1.43$ billion (1).

Swine intensive production confers relevant aspects with issues related to management control and herd uniformity, aside from presenting a good cost-benefit relationship. However, intensive confinement brought as consequence the increase in diseases due to excessive production of animals per floor area (2), influencing the animals' well-being and the sanitary profile of production. The direct consequence of the increase in diseases during rearing is a high carcass commendation index in commercial slaughterhouses.

Swine carcass inspection during slaughter is used for evaluating the health of the herd, and the output data may help in epidemiologic studies, and in identifying risk factors involving prevalence of lesions $(3,4)$.

Factors related to the management of the animals, especially regarding pre-slaughter management can lead to a considerable increase in the incidence of carcass condemnations, which aside from causing direct losses to slaughterhouses; can generate barriers for increasing demand for pork exports (5).
Considering the loss from condemned carcasses recorded in commercial slaughterhouses, this study aimed to evaluate the causes of carcass condemnation as well as to estimate the loss as a function of their occurrence.

\section{MATERIAL AND METHODS}

Animals and husbandry. The research was conducted in a commercial slaughterhouse, located in Dourados, MS, Brazil, with latitude $22^{\circ} 13^{\prime} \mathrm{S}$, longitude $54^{\circ} 48^{\prime} \mathrm{W}$ and altitude of 430 $\mathrm{m}$. The regional climate according to Köppen classification is Aw (tropical climate with rainy season in summer and dry in winter). The industry has a Federal Inspection Service (SIF) and slaughter capacity of 2,300 heads per day, representing approximately $50 \%$ of the daily slaughter of the State of Mato Grosso do Sul. Most swine production systems integrated to the company are located in the same city or in its surroundings, at an average distance of $100 \mathrm{~km}$ from the slaughterhouse.

The swine rearing facilities adopted by the integrator were standardized, and animals in the units producing piglets are raised in suspended cages while the finishing units are in pens with running water on the back part of the pen. All integrated units practice the same vaccination scheme (Table 1 ). The disinfection system adopted is "all in all out" with 15 days emptyperiod between rearing herds. 
Table 1. Vaccination scheme adopted by the integrator for all the animals destined for slaughter.

\begin{tabular}{lc}
\hline \multicolumn{1}{c}{ Vaccine } & Age (days) \\
\hline Streptococcus suis & 7 e 21 \\
Haemophilus parasuis & 7 e 21 \\
Micoplasma hyopneumoniae & 15 \\
Circovirus & 15 \\
\hline
\end{tabular}

The pre-slaughter management adopts fasting time prior to transport of about six hours. After fasting, the heavier animals per pen were selected and targeted for shipment with the use of tarps and the aid of rattles (plastic bottle with stones), and management planks. From this time on, the herd is mixed. The pigs enter the truck using ramps with lifts and are wetted after shipment. Pigs are transported to the slaughterhouse in trucks with 16-24 divisions, equipped with aluminum body and double floors. The adopted density for transporting the pigs is $250 \mathrm{~kg}$ per $\mathrm{m}^{2}$.

After arrival to the commercial slaughterhouse, the pigs are downloaded using a ramp, and on the reception platform, they are showered. After the shower, they are tattooed with non-toxic paint, and they are sent to the rest pens, where they are housed in an area of $0.65 \mathrm{~m}^{2}$ per pig. After a standard rest period adopted by the company of at least six hours (ranging from six to maximum of 10 hours), the pigs are directed to slaughter by employees using guiding sticks up to the stunning hall. Pigs are slaughtered following conventional protocol after stunning by electro narcosis.

Data recording. The percentage of carcass condemnation between 2007 and 2009 was analyzed. These annual percentages were calculated, based on the total slaughtered per year (401.278 in 2007; 453.553 in 2008; and 514.501 in 2009). The mean carcass weight was $96.3 \mathrm{~kg}$, $94.0 \mathrm{~kg}$ and $92.3 \mathrm{~kg}$ for the years 2007, 2008 and 2009 , respectively. Data on total and partial carcass condemnation was recorded, and the most frequent causes were classified into five groups as a function of condemnation (Table 2).

Table 2. Grouping by classes of swine carcass condemnation recorded in a commercial slaughterhouse between 2007 and 2009.

\begin{tabular}{lc}
\hline Class de condemnation & Pathology or Condition \\
\hline Condemnation 1 (Cond 1 ) & Pleuresy + Pneumonia \\
Condemnation 2 (Cond 2) & Enteritis \\
Condemnation 3 (Cond 3 ) & Arthritis \\
Condemnation 4 (Cond 4) & Abscesses \\
Condemnation 5 (Cond 5) & Fracture/Hematomas + Contusion +Death \\
\hline
\end{tabular}

Group 4 of condemnation (abscesses), included the total and partial condemnations, independently of the location of the edema in the carcass.

For the economic loss analysis from total and partial carcass condemnations, the total amount of carcass produced and condemned (total and partial) were computed from 2007 to 2009. To calculate the economic loss the number of carcass condemned was considered, the final destinations of the meat from this carcass (grease, cooked products), considering its market value in relation to the average value of the ham and shoulder cuts (in dollars price of April 26.2012 - U\$ 2.72). The difference between these values was used to calculate the amount lost by the slaughterhouse during the three years.

Data analysis. Descriptive analysis was performed to verify the data in a comparative way. Data was evaluated individually in order to verify the behavior of the variables over the period studied. These results provided support for exploratory analysis. Exploratory analysis is characterized to validate conclusions drawn from the descriptive analysis, and comparisons were given through intervals of $95 \%$ confidence. The Principal Components Analysis was applied to verify the association between the causes of carcass condemnation. The software Minitab (6) was used to calculate data, and to apply the Kruskal-Wallis test using 5\% confidence.

\section{RESULTS}

Condemnation scenario as a function of the year (2007 to 2009). Taking into account the sum of all the observed causes of carcass condemnations over the three years, the rates of total condemnations were low and tended to stability (Table 3 ). The distributions of the percentage of carcass condemnations were asymmetric, and increased during the period between 2007 and 2009, with higher distances between the mean and median of their respective distributions. The asymmetry also caused an increase in the dispersion measurements such as the standard deviation and coefficients of variation. However, despite the growing asymmetry, there was no increase in the total percentage of condemnations over the years $(p>0.05)$.

Considering the individual reasons for carcass condemnation, the highest incidence during the study period were abscesses and death during transport, each of which presented a percentage higher than $20 \%$ of all condemnations during the three years, with a tendency to increase between the years 2007 to 2009 (Figure 1). 
Table 3. Causes and percentages (absolute and relative) of carcass condemnation (total and partial) in swine commercial slaughterhouse from 2007 to 2009.

\begin{tabular}{|c|c|c|c|c|c|c|}
\hline \multirow{3}{*}{$\begin{array}{l}\text { Cause of de } \\
\text { condemnation }\end{array}$} & \multicolumn{6}{|c|}{ Percentage (\%) } \\
\hline & \multicolumn{2}{|c|}{2007} & \multicolumn{2}{|c|}{2008} & \multicolumn{2}{|c|}{2009} \\
\hline & Absolute & Relative & Absolute & Relative & Absolute & Relative \\
\hline Abscesses & 0.1039 & 23.68 & 0.1105 & 24.80 & 0.1240 & 28.92 \\
\hline Adenitis & 0.0000 & 0.00 & 0.0002 & 0.04 & 0.0002 & 0.05 \\
\hline Arthritis/Polyarthritis & 0.0299 & 6.81 & 0.0137 & 3.08 & 0.0190 & 4.43 \\
\hline Cachexy & 0.0010 & 0.23 & 0.0075 & 1.68 & 0.0052 & 1.21 \\
\hline Contusions & 0.0005 & 0.11 & 0.0007 & 0.16 & 0.0012 & 0.28 \\
\hline Cryptorchidism & 0.0329 & 7.50 & 0.0134 & 3.01 & 0.0014 & 0.33 \\
\hline Emergency & 0.0643 & 14.65 & 0.0591 & 13.27 & 0.0086 & 2.01 \\
\hline Enteritis & 0.0030 & 0.68 & 0.0009 & 0.20 & 0.0010 & 0.23 \\
\hline Fractures/Hematomas & 0.0202 & 4.60 & 0.0661 & 14.84 & 0.1145 & 26.71 \\
\hline Icterus/Adipoxant. & 0.0002 & 0.05 & 0.0004 & 0.09 & 0.0006 & 0.14 \\
\hline Slimness & 0.0067 & 1.53 & 0.0002 & 0.04 & 0.0052 & 1.21 \\
\hline Death during handling & 0.0095 & 2.16 & 0.0057 & 1.28 & 0.0043 & 1.00 \\
\hline Death during transport & 0.1062 & 24.20 & 0.1274 & 28.60 & 0.1155 & 26.94 \\
\hline Death at rearing & 0.0005 & 0.11 & 0.0000 & 0.00 & 0.0000 & 0.00 \\
\hline Peritonitis & 0.0202 & 4.60 & 0.0251 & 5.63 & 0.0220 & 5.13 \\
\hline Pleurisy & 0.0224 & 5.10 & 0.0060 & 1.35 & 0.0054 & 1.26 \\
\hline Pneumonia & 0.0145 & 3.30 & 0.0018 & 0.40 & 0.0004 & 0.09 \\
\hline Mange / Dermatitis & 0.0007 & 0.16 & 0.0004 & 0.09 & 0.0002 & 0.05 \\
\hline Tumors/Neoplasia & 0.0022 & 0.50 & 0.0064 & 1.44 & 0.0000 & 0.00 \\
\hline Total & 0.4388 & 100 & 0.4455 & 100 & 0.4287 & 100 \\
\hline
\end{tabular}

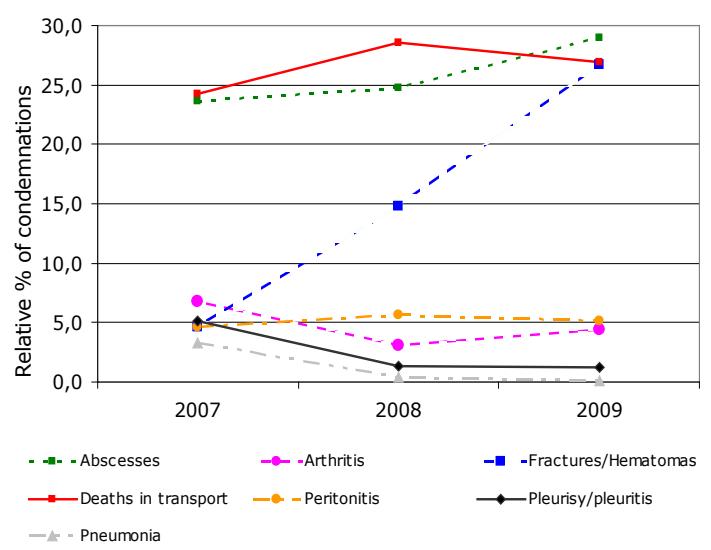

Figure 1. Relative percentage of the main causes of swine carcass condemnation in a commercial slaughter house from 2007 to 2009.

There was an increase in carcass condemnations by fractures and hematomas, which in 2007 accounted for only $4.60 \%$ of total condemnations, increasing to $26.7 \%$ of the condemnations which occurred in 2009. Considering only the condemnations of the five classes grouped in table 1 , the difference in the percentage of condemnation by fractures/ hematomas, contusions and death (Cond 5 ) is higher $(p<0.01)$ than the others. The second cause of carcass condemnation was the presence of abscesses (Cond 4), and the lowest cause was enteritis (Cond 2). Condemnation by respiratory problems (Cond 1 ) and arthritis (Cond 3 ) were at intermediate levels (Figure 2).

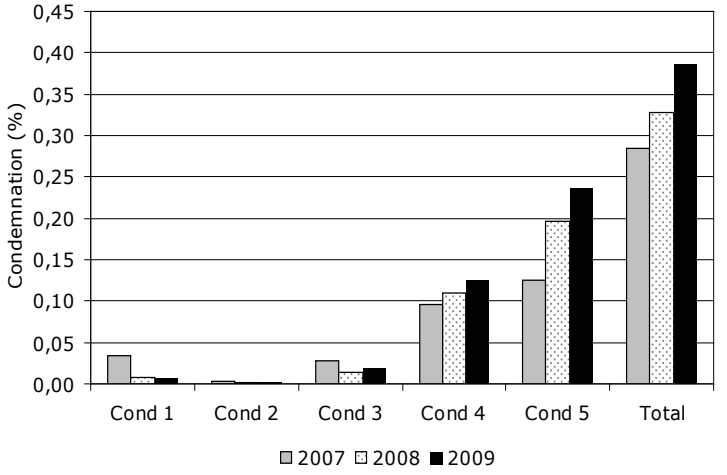

Figure 2. Profile of carcass condemnation classes in a commercial swine slaughterhouse from 2007 to 2009.

The condemnations related to health problems (Cond 1, Cond 2, and Cond 3 ) tended to reduce or remain stable over the years. However, condemnations caused by management problems (Cond 5 - fractures, bruises and death) showed a significant increase during the period. In general, the profile of total condemnations increased in 2009, given the increase in Cond 5.

The carcass condemnations caused by the presence of abscesses (Cond 4), which may be caused by factors both related to health management, presented a slight increase over the years $(23.68 \%$ to $28.92 \%$ of total condemnations), although it was not significant. 
It is believed that this fact may be related to the adoption of the immune-castration technique, by producers, which requires the application of two vaccine doses in the animals, about 30 to 60 days prior to slaughter, which could lead to a higher probability of occurrence of restricted abscesses.

Condemnations due to abscesses, arthritis, and pleurisy plus pneumonia in 2007 showed greater variability and asymmetric results, in relation to subsequent years. However, only the condemnations in Class 5 (fractures, bruises plus death) differed $(p<0.05)$ between the studied years.

Direct relationship between the various forms of condemnation was observed mainly in those caused by specific diseases (Pleurisy + pneumonia, enteritis and arthritis). The increase of the causes of condemnation relates high and positively with the increase of each one of the other two. The close relationship between condemnation by arthritis, enteritis and respiratory problems (diseases caused by multiple factors) may reflect low immune status of the herd, where the access of certain pathogens in the body facilitates the incursion of others in immunosuppressed animals.

Economic loss analysis derived from total and partial carcass condemnations. Although the overall rates of condemnations have been relatively low, compared to other stated in the literature, the loss was significant. To calculate the slaughter industry financial loss the following items were considered as follows: a) the quantities in kilograms of the condemned carcass by assessed year (total or partial condemnation). b) the market price equal to the product for which the carcasses condemned were destined (grease, cooked products and carcasses of animals that arrive dead to the slaughterhouse) and the average market price of the cuts ham and shoulder (Table 4). Considering the difference between the amount actually obtained from the sale of condemned carcasses, in the form of cooked products or for grease, and the amount that would be received in the form of frozen cuts, it is observed that the industry lost, during three years, an amount greater than US\$1.600.000.

Although this value represents around $1 \%$ of the net profit of the slaughter industry, it would be rewarded if invested in training the teams that perform the pre-slaughter management, since the main causes of condemnation of carcasses found were from failure in management.

Indirect loss caused by reduced performance and increased use of drugs in animals suffering from certain diseases during the rearing period, should also be considered in the analysis; however they are difficult to assess.

\section{DISCUSSION}

The high percentage of carcass condemnations by death during transportation, bruises, and fractures, may be related to the lack of training and knowledge of the principles of animal welfare, by employees responsible for preslaughter management, during truck loading, transport and unloading operations.

The transport of live pigs remains a critical point in the Brazilian pig production chain. The handling procedures during pre-slaughter where animals from different origins are grouped, increases stress and leads to fighting (7). Amongst the stages of pre-slaughter management, boarding, transportation and arrival, are considered steps of increased stress. This might be due to the interaction of man with the pig, environmental changes, and the difficulty of the animals to move on ramps $(8,9)$. At that moment, fear and stress are predominant, which trigger a physiological overload of stress in the animals. The lack of skilled teams to perform this operation has shown damage to animal welfare and meat quality (10), imposing economic loss to the industry. Additional to increasing mortality rates,

Table 4. Financial losses in studied slaughter industry caused by swine carcass condemnation from 2007 to 2009.

\begin{tabular}{|c|c|c|c|c|c|c|c|}
\hline \multirow{2}{*}{ Destination } & \multirow{2}{*}{ MV (U\$) } & \multicolumn{2}{|c|}{2007} & \multicolumn{2}{|c|}{2008} & \multicolumn{2}{|c|}{2009} \\
\hline & & kg & U\$ & kg & U\$ & kg & U\$ \\
\hline GRE & 1.53 & 255.967 & $391,629.51$ & 336.305 & $514,546.65$ & 375.129 & $573,947.37$ \\
\hline $\mathrm{CP}$ & 2.22 & 86.455 & $191,930.10$ & 73.145 & $162,381.90$ & 62.754 & $139,313.88$ \\
\hline DT & 0.03 & 41.024 & $1,230.72$ & 54.332 & $1,629.96$ & 54.826 & $1,6444.78$ \\
\hline Total & & 383.446 & $584,790.33$ & 463.782 & $678,558.51$ & 492.709 & $714,906.03$ \\
\hline APP & 2.72 & & $1,042,973.12$ & & $1,261,487.04$ & & $1,340,168.48$ \\
\hline Loss & & & $458,182.79$ & & $582,928.53$ & & $625,262.45$ \\
\hline
\end{tabular}

MV - market value; GRE- total or partially condemned carcasses used for grease; CP - total or partially condemned carcasses used for cooked products; DT - death at transportation; APP - total amount that could be collected if sold by the price of ham and shoulder. 
inadequate management during transport, it is also responsible for the incidence of contusions, fractures and hematomas, which compromise the quality of meat, especially of prime cuts such as ham, loin and shoulder.

Transport to the slaughterhouse is a considerable stress burden for pigs. The stress burden level of pigs is especially influenced by the treatment method of the animals at the point of loading, during transport, unloading from the transport means and before slaughter, and further by the grouping of animals for transport, loading density, transport distance and transportation time, transport method, feeding and medication of feed-stuffs before transport of the animals (11). The transport increases pig mortality, not only transport of longer distances (8 hours journey time), but also transport over very short distances (1 hour) (12), as well as being influenced by temperature, being higher in the summer (12) and by genetic predisposition (12).

Lung diseases are amongst the greatest health problems of swine production. Typically, lesions of enzootic pneumonia are also associated with pleurisy during slaughter, and pigs that develop the disease early in life are more likely to experience pleurisy at slaughter (13). This can be verified by the reduction in the incidence of pneumonia between the years 2007 to 2009 which was also followed by a reduction of carcass condemnations by pleurisy (Figure 1). In many countries, pulmonary lesions are reported as a considerable health problem responsible for carcass condemnation (14-17). There are few studies in literature describing the characteristics of the respiratory lesions responsible for carcass condemnations, as well as the criteria adopted in different countries for the classification of carcasses and target lesions. During routine inspections in Brazilian slaughterhouses, there is a variation in the testing and destination of carcasses with different lung lesions by different inspectors. The destinations of carcasses diagnosed with pneumonia in recent years are for cooked product $(70.6 \%)$, for grease $(28 \%)$, and for byproducts $(1.4 \%)$, and the carcasses destined for cooking processes, production of grease and byproducts, has a devaluation of 12 , 85 and $92 \%$, respectively for the industry (SIF unpublished data).

When studying the reasons for condemnation of pig carcasses with retarded growth (17), a total of $8.5 \%$ of condemnations were observed. From this amount, $55.8 \%$ of carcasses were condemned due to abscesses, $28.9 \%$ due to cachexia, $7.4 \%$, due to arthritis, $6.4 \%$ due to fibrous pleurisy, $6.4 \%$ due to fibrous peritonitis, and $5.5 \%$ due to pleuro-pneumonia. In this study, only $0.8 \%$ of the pigs died during transportation. However, when studying the incidence of carcass condemnations in apparently healthy pigs, the authors observed values of 0.2 and $0.5 \%$ for total and partial condemnations, respectively. Several factors must be taken into account to assess the type and frequency of the lesions observed, in relation to other studies. The climate, herd management and overall health status, may vary from one region to another, leading to distinct final carcass qualities.

In conclusion the total carcass condemnations index was relatively low, and the causes related to health problems tended to be stable. However, condemnations caused by failures during the pre-slaughter management (fractures, hematomas, contusions and death), presented an increase over the years, enhancing the need for staff training. The amount annual loss by the slaughter company should be invested in the training of employees aiming to reduce rates of condemnations due to failure in pre-slaughter management.

\section{REFERENCES}

1. Associação Brasileira de Produtores e Exportadores de Carne Suína (Abipecs) [homepage na internet]. [acesso em 27 jan 2012]. Disponível em: http:www.abipecs. com.br.

2. Sobestianky J, Martins MIS, Barcellos DESH, Sobral VBGM. Formas anormais de comportamento dos suínos: possíveis causas e alternativas de controle. Concórdia: EMBRAPA-CNPSA; 1991.
3. Maes DG, Deluyker H, Verdonck M, Kruif A, Ducatelle R, Castryck $F$ et al. Non-infectious factors associated with macroscopic and microscopic lung lesions in slaughter pigs from farrow-to-finish herds. Vet Rec 2001; $148(2): 41-46$.

4. Walker PK, Bilkei G. Tail-biting in outdoor pig production. Vet J 2006; 171 (2):367-369. 
5. Yeates JW, Main DC. Assessment of positive welfare: A review. Vet J 2008; 175(3):293-300.

6. Minitab Inc. Minitab ${ }^{\circledR}$ 15.1.0.0. State College, 2006.

7. Bench C, Schaefer A, Faucitano L. The welfare of pigs during transport. In: Schaefer A, Faucitano L. Welfare of pigs: from birth to slaughter. New York: Wageningen Academic; 2008, 6:161-180.

8. Averós X, Knowles T, Brown SN, Warriss PD, Gosálvez LF. Factors affecting the mortality of pigs being transported to slaughter. Vet Rec 2008; 163:386-390.

9. Averós X, Knowles T, Brown SN, Warriss PD, Gosálvez LF. Factors affecting the mortality of weaned piglets during commercial transport between farms. Vet Rec 2010; 167:815-819.

10. Lambooij E, Hulsegge B, Klont RE, Winkelman-Goedhart HA, Reimert HG, Kranen RW. Effects of housing conditions of slaughter pigs on some post-mortem muscle metabolites and pork quality characteristics. Meat Sci 2004; 66(4):855-862.

11. Vecerek V, Malena M, Malena Jr M, Voslarova E,Chloupek P. The impact of the transport distance and season on losses of fattened pigs during transport to the slaughterhouse in the Czech Republic in the period from 1997 to 2004. Vet Med 2006; 51(1):21-28.
12. Werner C, Reiners K, Wicke M. Mortality rates during transport of slaughter pigs. Fleischwirtschaft 2005; 85:135-136.

13. Andreasen M, Mousing J, Thomsen LK. No simple association between time elapsed from seroconvertion until slaughter and the extent of lung lesions in Danish swine. Prev Vet Med 2001; 52(2):147-161.

14. Frailea $L$, Alegrea $A$, López-Jiménez $R$, Nofraríasa $M$, Segalés J. Risk factors associated with pleurisy and cranio-ventral pulmonary consolidation in slaughter-aged pigs. Vet J 2010; 183(3):326-333.

15. Merialdi G, Dottori M, Bonilauri P, Luppi A, Gozio S, Pozzi P, et al. Survey of pleuritis and pulmonary lesions in pigs at abattoir with a focus on the extent of the condition and herd risk factors. Vet J 2012; 193(1):234-239.

16. Liljegren C.H, Aalbaek B, Nielsen OL, Jensen $\mathrm{HE}$. Some new aspects of the pathology, pathogenesis, and aetiology of disseminated lung lesions in slaughter pigs. APMIS 2003; 111(5):531-538.

17. Martínez J, Jaro PJ, Aduriz G, Gómez EA, Peris B, Corpa JM. Carcass condemnation causes of growth retarded pigs at slaughter. vet J 2007; 174(1):160-164. 